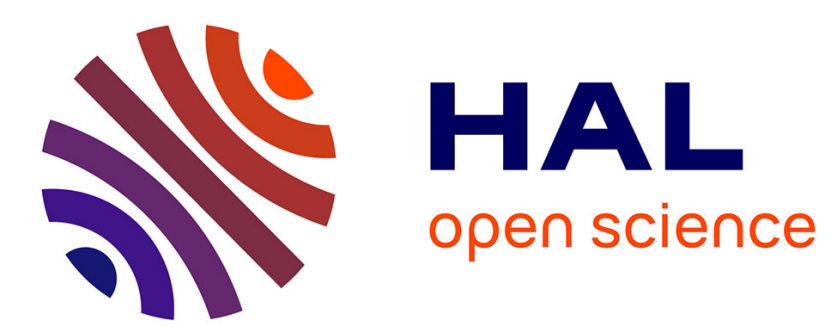

\title{
Effects of patriline on gustatory responsiveness and olfactory learning in honey bees
}

\author{
Ricarda Scheiner, Gérard Arnold
}

\section{To cite this version:}

Ricarda Scheiner, Gérard Arnold. Effects of patriline on gustatory responsiveness and olfactory learning in honey bees. Apidologie, 2010, 41 (1), 10.1051/apido/2009040 . hal-00892040

\section{HAL Id: hal-00892040 \\ https://hal.science/hal-00892040}

Submitted on 1 Jan 2010

HAL is a multi-disciplinary open access archive for the deposit and dissemination of scientific research documents, whether they are published or not. The documents may come from teaching and research institutions in France or abroad, or from public or private research centers.
L'archive ouverte pluridisciplinaire HAL, est destinée au dépôt et à la diffusion de documents scientifiques de niveau recherche, publiés ou non, émanant des établissements d'enseignement et de recherche français ou étrangers, des laboratoires publics ou privés. 


\title{
Effects of patriline on gustatory responsiveness and olfactory learning in honey bees*
}

\author{
Ricarda SCHEINER ${ }^{1}$, Gérard ARNOLD ${ }^{2}$ \\ ${ }^{1}$ Institut für Ökologie, Technische Universität Berlin, Franklinstr. 28/29, 10587 Berlin, Germany \\ ${ }^{2}$ CNRS UPR 9034, Laboratoire Évolution, Génomes, Spéciation (LEGS), 91198 Gif-sur-Yvette, France
}

Received 6 January 2009 - Revised and accepted 15 April 2009

\begin{abstract}
Associative proboscis extension learning differs widely among bees of a colony. This variety of performances is often related to differences in sucrose responsiveness, which determines learning performance. Sucrose responsiveness is partly determined genetically. We studied for the first time effects of paternal genes on associative learning independent of sucrose responsiveness. To do this, we used wild-type workers stemming from five unrelated patrilines. Bees of the patrilines were first tested for sucrose responsiveness. Only bees with equal sucrose responsiveness were analysed for associative olfactory learning, memory and discrimination. The bees of different patrilines did not differ in their acquisition, memory or discrimination of odours when they had similar sucrose responsiveness. But patrilines differed significantly in their sucrose responsiveness. This shows genetic effects on sensory responsiveness but no independent effects on associative learning.
\end{abstract}

olfactory conditioning / insect / paternal effects / genes / gustatory responsiveness / reward

\section{INTRODUCTION}

Honey bees are important models for studying the mechanisms of learning and memory, because they display diverse forms of learning even under restricted laboratory conditions (Menzel and Müller, 1996; Giurfa, 2007). The most frequently used paradigm for studying learning and memory in bees is olfactory conditioning of the proboscis extension response (PER). The proboscis response is elicited when the antennae of a bee are touched with a sucrose solution whose concentration exceeds the individual response threshold of the bee. This response can be conditioned to an odour if the odour precedes the sucrose stimulation and if the bee is allowed to drink sucrose solution after extending her proboscis (Kuwabara, 1957).

Corresponding author: R. Scheiner, Ricarda.Scheiner-Pietsch@TU-Berlin.de * Manuscript editor: Stan Schneider
Despite sharing half of their genotype, female worker bees of a colony can differ strongly in their learning performance (for review see Scheiner et al., 2004a). This variation in performance is often regarded as "behavioural noise" and complicates studies analysing basic mechanisms of learning and memory.

A major reason for the diversity in PER learning performance is that bees of a colony differ in their sucrose responsiveness and therefore in their evaluation of the sucrose reward. Individual sucrose responsiveness can be measured by applying different sucrose concentrations to the antennae of a bee and observing which concentration elicits proboscis extension (for review see Scheiner et al., 2004a). Bees which have high sucrose responsiveness learn better than bees with low sucrose responsiveness, because they place a higher value on the sucrose solution used as reward (Scheiner et al., 1999, 2001a, b, c, 2005; Behrends et al., 2007). Thus, for example, 
pollen foragers learn better than nectar foragers, because they are more responsive to sucrose (Scheiner et al., 1999, 2001b, 2003). If bees with different sucrose responsiveness receive equal subjective rewards, based on their individual responsiveness, a large part of the observed learning differences disappear (Scheiner et al., 2005).

Sucrose responsiveness is partly determined genetically. In two strains of bees which were selected to either store large amounts of pollen ("high strain") or low amounts of pollen but high amounts of nectar ("low strain") (Hellmich et al., 1985; Page and Fondrk, 1995), several quantitative trait loci (QTLs) for foraging behaviour were mapped (for review see Hunt et al., 2007). Interestingly, two of these QTLs also correlate with sucrose responsiveness. One of them is pnll, a QTL for pollen hoarding behaviour (Hunt et al., 1995). The other one is $p \ln 4$, which is a marker for Amfor (Rueppell et al., 2004) and also correlates with aspects of foraging behaviour. These findings demonstrate a genetic basis of sucrose responsiveness.

In addition, the two genetic strains of bees differ in their associative tactile and olfactory learning, because they differ in their sucrose responsiveness (Scheiner et al., 2001a, b). However, it is unclear in how far genotype directly affects learning performance in honey bees, which is of great interest in the research of learning and its neuronal correlates in insects and vertebrates (Chen and Tonegawa, 1997; Dubnau and Tully, 1998). In honey bees, there is some evidence for genetic effects on associative proboscis extension learning (Brandes et al., 1988; Brandes 1991; Brandes and Menzel, 1990; Bhagavan et al., 1994) and latent inhibition learning (Chandra et al., 2000; Ferguson et al., 2001; Latshaw and Smith, 2005), but it is unclear whether all of the observed "genetic" learning differences can be directly attributed to differences in sucrose responsiveness.

We selected wild-type workers stemming from five unrelated patrilines with equal sucrose responsiveness for analysing their performance in olfactory PER learning. Olfactory acquisition, memory and discrimination were tested. After the behavioural experiments, the patriline of each bee was determined. These experiments enabled us to measure effects of patriline on associative learning parameters, independent of sucrose responsiveness.

\section{MATERIALS AND METHODS}

\subsection{Preparation of bees}

Behavioural experiments were conducted at the Technische Universität Berlin. The analysis of patriline was performed at the CNRS, Gif-sur-Yvette. A honey bee queen (Apis mellifera L.) was artificially inseminated with sperm from five unrelated drones. The queen was subsequently placed in a hive with five frames, bees, honey, pollen and brood. Frames with brood from the artificially inseminated queen were removed from the hive shortly before emergence of the bees and placed in an incubator maintained at $34{ }^{\circ} \mathrm{C}$ and $70 \%$ humidity. Emerging brood was paint marked and restored to the colony. At the age of two weeks, marked worker bees were collected from the hive and individually placed in glass vials. They were stored in a refrigerator maintained at $6{ }^{\circ} \mathrm{C}$ until they showed first signs of immobility. Then, each bee was mounted in a metal holder and strips of adhesive tape were fixed between head and thorax and over the abdomen. The bees rested for one hour before behavioural tests started.

\subsection{Measuring sucrose responsiveness}

First we measured sucrose responsiveness of all bees to later select bees with similar high sucrose responsiveness for the learning assays. This way we could separately analyse effects of patriline on sensory responsiveness and associative learning, memory and discrimination.

We used the proboscis extension response (PER) to measure responsiveness to the following sucrose concentrations: $0 \%, 0.1 \%, 0.3 \%, 1 \%, 3 \%, 10 \%$, $30 \%$, which were offered in ascending order. Each bee was stimulated with a droplet of each sucrose concentration at her antennae and it was recorded whether the bee showed proboscis extension. The inter-stimulus interval was $2 \mathrm{~min}$ to prevent sensitisation effects. To compare sucrose responsiveness between groups, we calculated a gustatory response score (GRS). This score comprises the sum 
of responses to the seven different sucrose concentrations. The GRS has been shown to be an excellent indicator of responsiveness to light, odours and pollen (Scheiner et al., 2004a), although responsiveness to electric shock, which is part of a different behavioural syndrome, does not correlate with sucrose responsiveness (Roussel et al., 2009).

Only bees with equal sucrose responsiveness were selected for conditioning to test for effects of patriline on learning independent of sucrose responsiveness. We selected bees with a GRS of five to seven, because bees with these GRS usually learn similarly well. Lower GRS lead to gross differences in learning performance (Scheiner et al., 2004a). Bees selected for the learning assay were conditioned directly after their responsiveness had been determined.

\subsection{Olfactory conditioning of the proboscis extension response}

For olfactory conditioning we used citral as CS+ and carnation oil as alternative stimulus (Scheiner et al., 2001a). Each bee was placed in front of a tube of $0.5 \mathrm{~cm}$ diameter, through which a constant air stream was blown at her antennae. The odours were added to the air stream by opening a valve of a channel that contained a piece of cellulose soaked with either $2 \mu \mathrm{L}$ of citral or $5 \mu \mathrm{L}$ of carnation oil. Before conditioning, each bee was tested for her spontaneous response to either odour. Bees that showed spontaneous proboscis extension to either citral or carnation oil were excluded from the further experiment. The number of bees responding spontaneously to either odour was very small and therefore not analysed statistically.

The acquisition phase consisted of five trials. In each trial the CS+ (citral) was presented for three seconds before proboscis extension was elicited by applying a droplet of $30 \%$ sucrose solution to either antenna, and the bee was allowed to drink from that sucrose droplet for about one second. This amounts to approximately $0.2 \mu \mathrm{L}$ sucrose solution for each bee. As all bees were given the same time for sucking the sucrose solution, we assume that all bees received the same volume of reward. Conditioned proboscis extensions were recorded. The "acquisition score" of a bee is defined as the total number of conditioned responses during the acquisition phase. After conditioning, we tested extinction of conditioned responses and discrimination between the conditioned odour and the alternative odour car- nation oil in five tests for each odour in pseudorandomised order. Only bees which had at least shown one conditioned response during the acquisition phase were tested for extinction and discrimination. The sum of conditioned responses in the five tests with citral constitutes the extinction score of a bee. For analysis of discrimination we calculated a discrimination index as follows (Scheiner et al., 2001a):

$$
\mathrm{DI}=\frac{\left(\mathrm{Ext}_{\text {citral }}-\mathrm{Ext}_{\text {carnation }}\right)}{\left(\mathrm{Ext}_{\text {carnation }}+\mathrm{Ext}_{\text {citral }}\right)}
$$

where: $\mathrm{DI}=$ discrimination index, Ext $_{\text {citral }}=$ sum of conditioned responses to the conditioned odour citral, Ext $_{\text {carnation }}=$ sum of responses to the alternative odour carnation oil. This discrimination index (DI) ranges from -1 to 1 . If DI equals 0 , no discrimination takes place. If DI $>0$, the bees prefer the conditioned odour, if DI $<0$, they prefer the alternative odour. Bees that did not respond in any of the discrimination tests received a discrimination index of 0 . The inter-trial interval was $5 \mathrm{~min}$ throughout the learning experiment. After the final test, bees were individually placed in $2 \mathrm{~mL}$ Eppendorf caps filled with ethanol and stored in a refrigerator until their patrilines were determined.

\subsection{Determination of patriline}

DNA was extracted according to Garnery et al. (1993) using a chelex-based protocol (Franck et al., 1999). To determine the patrilines of the bees, four highly polymorphic microsatellite markers (A76, A29, A107 and B124), identified by Estoup et al. (1994), were amplified in a PCR multiplex. PCR was performed using $10 \mu \mathrm{L}$ solution containing 5-10 ng DNA template, $400 \mathrm{nM}$ of each primer (primer sequences see Estoup et al., 1994), $75 \mu \mathrm{M}$ each of dGTP, dCTP and dTTP, $6 \mu \mathrm{M}$ dATP, $0.7 \mu \mathrm{Ci}$ $\left[{ }^{35} \mathrm{~S}\right] \mathrm{dATP}, 1-1.5 \mathrm{mM} \mathrm{MgCl}_{2}$ (depending on primer, for details see Estoup et al., 1994), $20 \mu \mathrm{g} \mathrm{mL}^{-1}$ bovine serum albumin, $1 \mathrm{X}$ Promega reaction buffer, and 0.4 unit of Promega Taq polymerase. After a denaturing step at $94{ }^{\circ} \mathrm{C}$ for $3 \mathrm{~min}$, samples were processed through 25 or 30 cycles (depending on primer, see Estoup et al., 2004). Each cycle consisted of $30 \mathrm{~s}$ at $94^{\circ} \mathrm{C}, 30 \mathrm{~s}$ at $54-60^{\circ} \mathrm{C}$ (depending on primer, for details see Estoup et al., 2004) and 30 $\mathrm{s}$ at $72{ }^{\circ} \mathrm{C}$. The last elongation step was prolonged to $10 \mathrm{~min}$.

Primer pairs were labelled respectively with 6FAM (blue), NED (yellow) and HEX (green). Amplified fragments were electrophoresed on an ABI 
Prism 310 Genetic Analyzer, equipped with Gene Scan Analysis software.

Relatedness between individuals was measured using the pedigree coefficient of relatedness introduced by Crozier (1970). The drones we used were unrelated to each other and to the queen. Therefore, the coefficient equalled 0.75 if two females stemming from the same queen belonged to the same patriline. If they belonged to different patrilines it was 0.25 .

\subsection{Statistics}

To test whether the five patrilines differed in their gustatory response scores (GRS), acquisition scores, extinction scores or discrimination indices, Kruskal Wallis Tests were performed, because the scores of some of the groups did not follow normal distribution. Pair-wise comparisons were done using Mann Whitney U Tests. The distributions of GRS were compared between groups using Kolmogorow Smirnow Z Tests. For tests of correlation between acquisition scores, extinction scores and discrimination indices we used Spearman rank correlation coefficients.

When we performed multiple tests from the same experimental sample, we applied the corresponding full Bonferroni correction (Miller, 1981) to the level of significance: the new $\alpha$ level to which the probabilities extracted from the Mann Whitney $\mathrm{U}$ Tests were compared was $\alpha^{\prime}=0.0127$ in order to detect a significant difference with a confidence level of $5 \%$.

\section{RESULTS}

\subsection{Patriline affects sucrose responsiveness}

Patriline affected sucrose responsiveness significantly $\left(\chi^{2}=26.27, P \leqslant 0.001\right.$, Kruskall Wallis Test). Patriline A was significantly more responsive than patriline $\mathrm{E}(\mathrm{Z}=4.72$, $P \leqslant 0.001$, Mann Whitney U Test). Also, the distribution of gustatory response scores was significantly different between these two patrilines (Fig. 1; $\mathrm{Z}=2.46, P \leqslant 0.001$, Kolmogorow Smirnow Z Test). The other patrilines displayed an intermediate distribution of GRS classes and did not differ in their sucrose responsiveness.

\subsection{Patriline has no independent effect on olfactory acquisition}

To study direct effects of patriline on olfactory acquisition, independent of sucrose responsiveness, we only conditioned bees with similar sucrose responsiveness. These were bees with a GRS of 5 to 7, because they perform similarly in learning assays (see Materials and Methods). Consequently, the GRS of conditioned bees did not differ between patrilines $\left(\chi^{2}=6.41, P=0.171\right.$, Kruskall Wallis Test).

Patriline had no independent effect on olfactory acquisition scores $\left(\chi^{2}=8.08, P=\right.$ 0.091, Kruskall Wallis Test). The median acquisition scores of bees with similar sucrcose responsiveness of the 5 different patrilines were almost identical (Fig. 2A).

\subsection{Patriline has no independent effect on olfactory extinction and discrimination}

Patriline also had no independent effect on extinction scores $\left(\chi^{2}=5.01, P=\right.$ 0.287, Kruskall Wallis Test). Median extinction scores were very similar between the different patrilines (Fig. 2B). Extinction scores correlated positively with acquisition scores ( $\rho=0.56, P \leqslant 0.001$, Spearman rank correlation). Bees with high acquisition scores displayed little extinction of conditioned responses.

Discrimination measured as discrimination index also strongly correlated with acquisition scores $(\rho=0.53, P \leqslant 0.001)$. Bees which displayed better acquisition also discriminated well, whereas those with poor learning performance discriminated poorly. Patriline had no independent effect on discrimination (Fig. 2C). There was no significant difference in the discrimination indices of the different patrilines $\left(\chi^{2}=2.28, P=0.68\right.$, Kruskall Wallis Test).

\section{DISCUSSION}

The aim of this study was to analyse in how far paternal genes directly affect associative learning performance, independent of 
Frequency of GRS classes in different patrilines
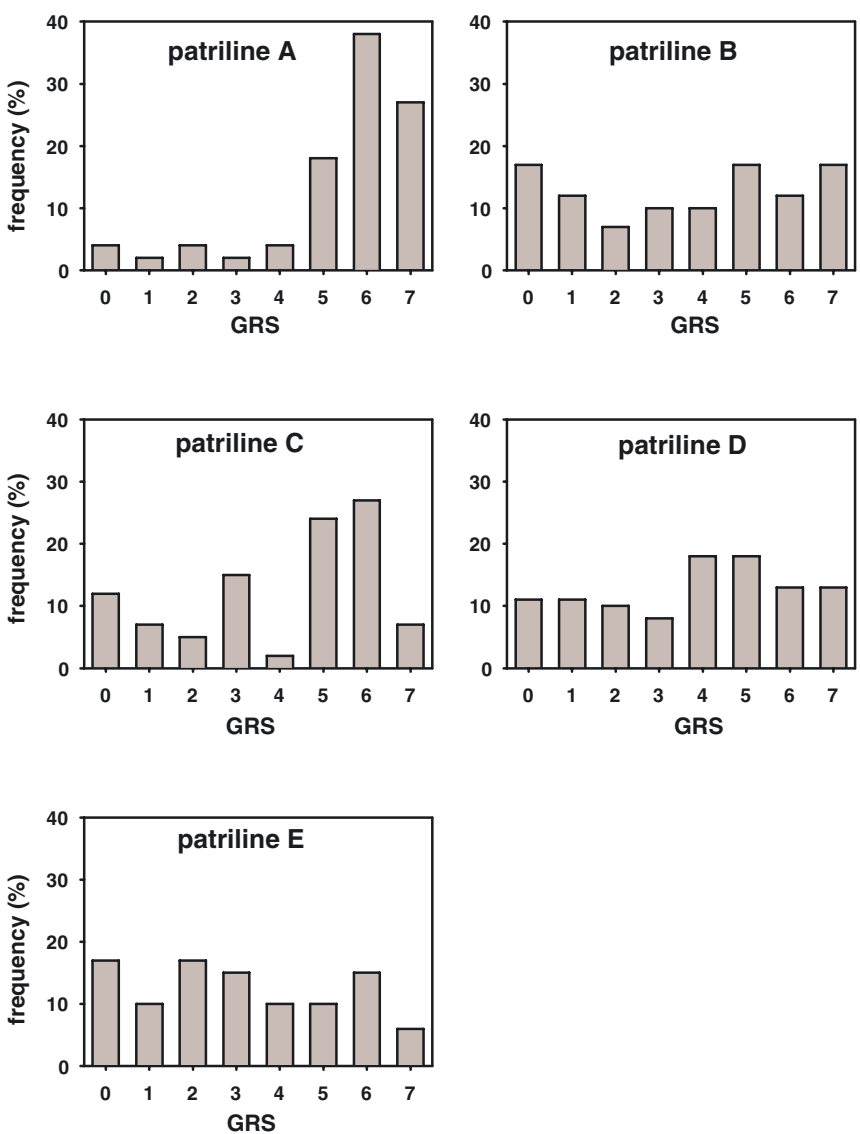

Figure 1. Distribution of gustatory response scores (GRS) for each patriline. The $x$-axis shows the GRS classes. The y-axis displays the relative frequency of bees in each patriline. Distributions of GRS differ significantly between patriline $\mathrm{A}$ and patriline $\mathrm{E}$ (for statistics see text). The numbers of bees tested in each patriline are as follows: A: 45, B: 42, C: 41, D: 63, E: 48.

sucrose responsiveness. Because sucrose responsiveness is a strong determinant of associative reward learning in bees (Scheiner et al., 2001a, b, c, 2003, 2005; Behrends et al., 2007; Scheiner and Amdam, 2009), we only tested bees with equal sucrose responsiveness for their performance in olfactory acquisition, memory and discrimination.

\subsection{Paternal effects on associative learning parameters}

The worker bees stemming from the five patrilines did not differ in their olfactory acquisition, extinction or memory performance, if they had similar sucrose responsiveness. This demonstrates that paternal genes had no effects on these learning parameters, independent of sucrose responsiveness. Both extinction and discrimination strongly depended on the level of acquisition. Bees which learned well and had high acquisition scores showed little extinction and good discrimination.

Honey bee colonies usually comprise worker bees from multiple patrilines, because the queen mates with up to 20 males (Gary, 1963; Page, 1986; Winston, 1987; Estoup et al., 1994). We therefore assume that 
Olfactory acquisition, extinction and discrimination of different patrilines
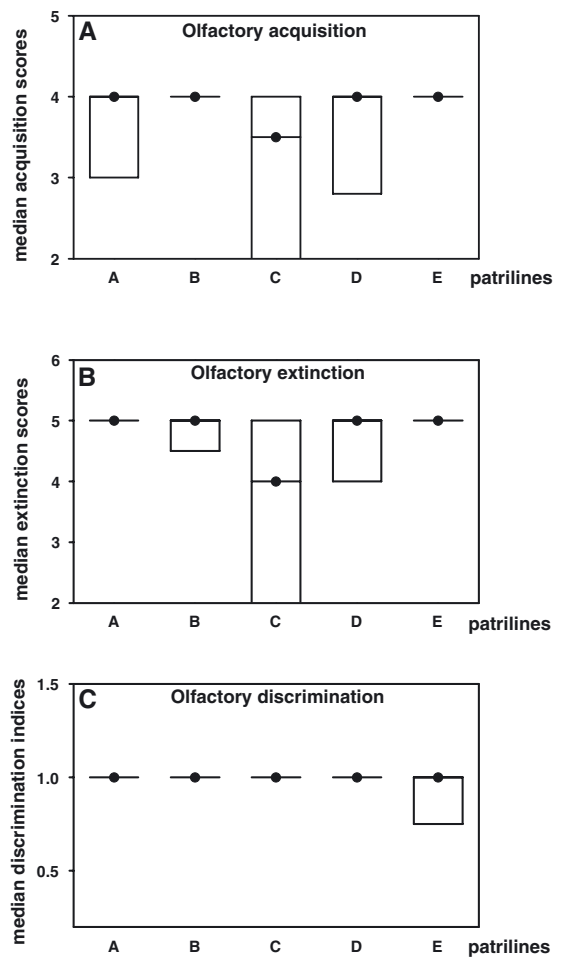

Figure 2. Median olfactory acquisition scores (A), median olfactory extinction scores (B), and median olfactory discrimination indices (C) and quartiles of conditioned bees in each patriline. Note that the bees of the different patrilines did not differ in their sucrose responsiveness. The $\mathrm{x}$-axis displays the different patrilines. The y-axis shows the median scores (dots) and the quartiles (lower line = $25 \%$ quartile, upper line $=75 \%$ quartile). The numbers of bees in (A) are: A: 31, B: 18, C: 18, D: 26, $\mathrm{E}: 13$. The numbers of bees in $(\mathrm{B})$ and $(\mathrm{C})$ are $\mathrm{A}$ : 28, B: 17, C: 17, D: 22, E: 12.

learning differences which can be observed between workers of a colony headed by a naturally mated queen are not directly related to a different composition of "learning genes" in the different patrilines. Instead, these learning differences are most likely related to differences in sensory responsiveness, which has strong genetic correlates (Hunt et al., 1995; Rueppell et al., 2004; Hunt et al., 2007). Our findings thus suggest that there are no specific "learning genes" in honey bees. Rather, all of the "genetic" learning differences described so far (Brandes et al., 1988; Brandes and Menzel, 1990; Bhagavan et al., 1994; Chandra et al., 2000, 2001; Ferguson et al., 2001; Scheiner et al., 2001a, b; Latshaw and Smith, 2005) are presumably results of genetically-based differences in the sensory system of the bees.

This makes it even more important to study the role of responsiveness to the reinforcer in experiments analysing the mechanisms of learning and memory. The search for "learning genes" or "memory genes" should be opened to genes determining sensory responsiveness. It is intriguing to speculate that at least some of the learning deficits found in Drosophila mutants (for review see Dubnau and Tully, 1998) are directly related to a reduced sensory responsiveness. This hypothesis can be tested, for example by measuring the sucrose responsiveness (Scheiner et al., 2004b) of mutants like turnip. These mutants practically display no appetitive olfactory learning using sucrose rewards (Tempel et al., 1983). In mutants deficient in olfactory avoidance learning, such as dunce and rutabaga (for review see Dubnau and Tully, 1998), an assay for measuring responsiveness to electroshocks needs to be established. A paradigm for measuring responsiveness to electroshocks in honey bees was recently established (Roussel et al., 2009).

\subsection{Paternal effects on sucrose responsiveness}

Our results show that paternal genes can have a significant effect on sucrose responsiveness. Two out of the five patrilines differed significantly in their gustatory response scores. This finding from wild-type bees adds to the results of studies which mapped genetic regions correlating with sucrose responsiveness in backcross populations of two selected strains of honey bees (see Introduction). Because a honey bee queen mates with multiple males (Gary, 1963; Page, 1986; Winston, 1987; Estoup et al., 1994), the composition of gustatory response scores in a colony will be much more diverse under natural conditions than in our experiment. Sucrose 
responsiveness correlates with responsiveness to other stimulus modalities (Scheiner et al., 2004a; Erber et al., 2006). We therefore assume that multiple mating of the queen increases the diversity of sensory response thresholds in a colony. This, in turn, results in a more flexible and appropriate allocation of workers to tasks (Page et al., 1995; Fuchs and Moritz, 1998; Palmer and Oldroyd, 2000). Jones et al. (2004) showed, for example, that genetically diverse colonies maintain a more homeostatic environment in the hive than genetically uniform colonies. A wide distribution of sucrose response thresholds among nectar foragers could lead to a more efficient exploitation of food sources under changing environmental conditions (such as nectar flow, weather, etc.) than a narrow distribution, because there will be bees accepting any sugar concentration available (Pankiw, 2003). Fuchs and Schade (1994) indeed showed that colonies headed by a single-mated queen had lower pollen and honey stores than colonies headed by a queen inseminated with semen from six drones.

\section{ACKNOWLEDGEMENTS}

We would like to thank Benedikt Polaczek for providing the bees and Marion Schröder for artificial insemination. In addition, we thank Hélène Legout for technical assistance.

Influence de la lignée paternelle sur la sensibilité gustative et l'apprentissage olfactif chez les abeilles (Apis mellifera).

conditionnement olfactif / effet paternel / gène / sensibilité gustative / récompense

\footnotetext{
Zusammenfassung - Einflüsse der Patrilinie auf die Zuckerwasserempfindlichkeit und das Duftlernen bei Honigbienen. Arbeiterinnen einer Honigbienenkolonie unterscheiden sich oft sehr stark in ihrem Rüsselreflex-Lernen. Diese Vielfalt im Lernverhalten hängt dabei häufig mit der individuellen Empfindlichkeit für den Belohnungsreiz Zuckerwasser zusammen. Die Zuckerwasserempfindlichkeit ist zumindest teilweise genetisch programmiert.
}

Wir haben zum ersten Mal untersucht, inwieweit väterliche Gene das assoziative Lernverhalten unabhängig von der Zuckerwasserempfindlichkeit beeinflussen. Dazu haben wir Arbeiterinnen untersucht, die von fünf nicht miteinander verwandten Patrilinien stammten. Von jeder Arbeiterin wurde zunächst die Zuckerwasserempfindlichkeit bestimmt. Anschließend wurden Bienen mit ähnlicher Empfindlichkeit auf ihr Duftlernen, ihr Gedächtnis und ihre Duftdiskriminierung getestet.

Bienen gleicher Zuckerwasserempfindlichkeit haben sich weder im Lernverlauf noch im Gedächtnis oder in der Diskriminierung unterschieden. Aber Bienen verschiedener Patrilinien unterschieden sich in ihrer Zuckerwasserempfindlichkeit. Unsere Ergebnisse zeigen daher keinen von der Zuckerwasserempfindlichkeit unabhängigen Effekt väterlicher Gene auf das Lernverhalten bei Bienen.

olfaktorische Konditionierung / Insekt / väterliche Einflüsse / Gene / gustatorische Empfindlichkeit / Belohnung

\section{REFERENCES}

Behrends A., Scheiner R., Baker N., Amdam G.V. (2007) Cognitive aging is linked to social role in honey bees (Apis mellifera), Exp. Gerontol. 42, 1146-1153.

Bhagavan S., Benatar S., Cobey S., Smith B.H. (1994) Effect of genotype but not of age or caste on olfactory learning performance in the honey bee, Apis mellifera, Anim. Behav. 48, 1357-1369.

Bonabeau E., Theraulaz G., Deneuburg J.L. (1996) Quantitative study of the fixed threshold model for the regulaton of division of labour in insect societies, Proc. R. Soc. London B 263, 1565-1569.

Bonabeau E., Theraulaz G., Deneuburg J.L. (1998) Fixed response thresholds and the regulation of division of labor in insect societies, Bull. Math. Biol. 60, 753-807.

Brandes C. (1991) Genetic differences in learning behavior in honeybees (Apis mellifera capensis), Behav. Genet. 21, 271-294.

Brandes C., Menzel R. (1990) Common mechanisms in proboscis extension conditioning and visual learning revealed by genetic selection in honeybees (Apis mellifera), J. Comp. Physiol. A 166, 545-552.

Brandes C., Frisch B., Menzel R. (1988) Time-course of memory formation differs in honey bee lines selected for good and poor learning, Anim. Behav. 36, 981-985.

Chandra S.B.C., Hosler J., Smith B.H. (2000) Heritable variation for latent inhibition and its correlation to reversal learning in the honeybee, Apis mellifera, J. Comp. Psychol. 114, 86-97. 
Chandra S.B.C., Hunt G.J., Cobey S., Smith B.H. (2001) Quantitative trait loci associated with reversal learning and latent inhibition in honeybees (Apis mellifera), Behav. Genet. 31, 275-285.

Chen C., Tonegawa S. (1997) Molecular genetic analysis of synaptic plasticity, activity-dependent neural development, learning and memory in the mammalian brain, Annu. Rev. Neurosci. 20, 157-184.

Crozier R.H. (1970) Coefficients of relationship and the identity of genes by descent in the Hymenoptera, Am. Nat. 104, 216-227.

Dubnau J., Tully T. (1998) Gene discovery in Drosophila: New insights for learning and memory, Annu. Rev. Neurosci. 21, 407-444.

Erber J., Hoorman, J., Scheiner R. (2006) Phototactic behaviour correlates with gustatory responsiveness in honey bees (Apis mellifera L.), Behav. Brain Res. 174, 174-180.

Estoup A., Solignac M., Cornuet J.M. (1994) Precise assessment of the number of patrilines and of genetic relatedness in honeybee colonies, Proc. R. Soc. London B 258, 1-7.

Ferguson H.J., Cobey S., Smith B.H. (2001) Sensitivity to a change in reward is heritable in the honeybee, Apis mellifera, Anim. Behav. 61, 527-534.

Franck P., Coussy H., Le Comte Y., Solignac M., Garnery L., Cornuet J.-M. (1999) Microsatellite analysis of sperm admixture in honey bee, Insect Mol. Biol. 8, 419-421.

Fuchs S., Moritz R.F.A. (1998) Evolution of extreme polyandry in the honeybee Apis mellifera L., Behav. Ecol. Sociobiol. 9, 269-275.

Fuchs S., Schade V. (1994) Lower performance in honeybee colonies of uniform paternity, Apidologie $25,155-168$.

Garnery L., Solignac M., Celebrano G., Cornuet J.-M. (1993) A simple test using restricted PCRamplified mitochondrial DNA to study genetic structure of Apis mellifera L., Experientia 49, 1016-1021.

Gary N.E. (1963) Observations of mating behavior in the honeybee, J. Apic. Res. 2, 3-9.

Giurfa M. (2007) Behavioral and neural analysis of associative learning in the honeybee: a taste from the magic well, J. Comp. Physiol. A 193, 801-824.

Hellmich R.L., Kulincevic J.M., Rothenbuhler W.C. (1985) Selection for high and low pollen-hoarding honey bees, J. Hered. 76, 155-158.

Hunt G.J., Amdam G.V., Schipalius D., Emore C., Sardesai N., Williams C.E., Rueppell O., GuzmanNovoa E., Arechavaleta-Velasco M., Chandra S., Fondrk K., Beye M., Page RE. (2007) Behavioral genomics of honeybee foraging and nest defense, Naturwissenschaften 94, 247-267.

Hunt G.J., Page R.E., Fondrk M.K., Dullum C.J. (1995) Major quantitative trait loci affecting honey bee foraging behavior, Genetics 141, 1537-1545.
Jones J.C., Myerscough M.R., Grahan S., Oldroyd B.P. (2004) Honey bee nest thermoregulation: diversity promotes stability, Science 305, 402-404.

Kuwabara M. (1957) Bildung des bedingten Reflexes von Pavlovs Typus bei der Honigbiene, Apis mellifica, J. Fac. Sci. Hokkaido Univ. Zool. 13, 458464.

Latshaw J., Smith B.H. (2005) Heritable variation in learning performance affects foraging preferences in the honey bee (Apis mellifera), Behav. Ecol. Sociobiol. 58, 200-207.

Menzel R., Müller U. (1996) Learning and memory in honeybees: From behavior to neural substrates, Rev. Neurosci. 19, 379-404.

Miller R.G. (1981) Simultaneous statistical inference, New York: Springer, pp. 6-8.

Page R.E. (1986) Sperm utilization in social insects, Annu. Rev. Entomol. 31, 297-320.

Page R.E., Fondrk M.K. (1995) The effects of colonylevel selection on the social organization of honey bee (Apis mellifera L.) colonies: colony-level components of pollen hoarding, Behav. Ecol. Sociobiol. 36, 135-144.

Page R.E., Erber J., Fondrk M.K. (1998) The effect of genotype on response thresholds to sucrose and foraging behavior of honey bees (Apis mellifera L.), J. Comp. Physiol. A 182, 489-500.

Page R.E., Robinson G.E., Fondrk M.K., Nasr M.E. (1995) Effects of genotypic diversity on honey bee colony development and behaviour (Apis mellifera L.), Behav. Ecol. Sociobiol. 36, 387-396.

Palmer K.A., Oldroyd B.P. (2000) Evolution of multiple mating in the genus Apis, Apidologie 31, 235 248.

Pankiw T. (2003) Directional change in a suite of foraging behaviors in tropical and temperate evolved honey bees (Apis mellifera L.), Behav. Ecol. Sociobiol. 54, 458-464.

Roussel E., Carcaud J., Sandoz J.-C., Giurfa M. (2009) Reappraising social insect behaviour through aversive responsiveness and learning, PLOS One 4, e4197. doi:10.1371/journal.pone.0004197.

Rueppell O., Pankiw T., Page R.E. (2004) Pleiotropy, epistasis and new QTL: The genetic architecture of honey bee foraging behaviour, J. Hered. 95, 481-491.

Scheiner R., Amdam G.V. (2009) Impaired tactile learning is related to social role in honey bees, $\mathrm{J}$. Exp. Biol. 212, 994-1002.

Scheiner R., Barnert M., Erber J. (2003) Variation in water and sucrose responsiveness during the foraging season affects proboscis extension learning in honey bees, Apidologie 34, 67-72.

Scheiner R., Erber J., Page R.E. (1999) Tactile learning and the individual evaluation of the reward in honey bees (Apis mellifera L.), J. Comp. Physiol. A, $185,1-10$. 
Scheiner R., Kuritz-Kaiser A., Menzel R., Erber J. (2005) Sensory responsiveness and the effects of equal subjective rewards on tactile learning and memory of honeybees, Learn. Memory 12, 626635.

Scheiner R., Page R.E., Erber J. (2001a) Responsiveness to sucrose affects tactile and olfactory learning in preforaging honey bees of two genetic strains, Behav. Brain Res. 120, 67-73.

Scheiner R., Page R.E., Erber J. (2001b) The effects of genotype, foraging role, and sucrose responsiveness on the tactile learning performance of honey bees (Apis mellifera L.), Neurobiol. Learn. Memory 76, 138-150.

Scheiner R., Weiß A., Malun D., Erber J. (2001c) Learning in honey bees with brain lesions: how partial mushroom-body ablations affect sucrose responsiveness and tactile antennal learning, Anim. Cogn. 3, 227-235.

Scheiner R., Page R.E., Erber J. (2004a) Sucrose responsiveness and behavioral plasticity in honey bees (Apis mellifera), Apidologie 35, 133-142.

Scheiner R., Sokolowski M.B., Erber J. (2004b) Activity of cGMP-dependent protein kinase (PKG) affects sucrose responsiveness and habituation in Drosophila melanogaster, Learn. Memory $11,303-311$.

Tempel B.L., Bonini N., Dawson D.R., Quinn W.G. (1983) Reward learning in normal and mutant Drosophila, Proc. Natl Acad. Sci. USA 80, 14821486.

Winston ML. (1987) The biology of the honey bee, London: Harvard University Press. 